\title{
Culicoides castelloni sp. nov. from the Brazilian Amazon Region with a revision of the reticulatus species group (Diptera, Ceratopogonidae)
}

\author{
MARIA CLARA A. SANTARÉM ${ }^{1,2}$, EMANUELLE S. FARIAS $^{3}$ \\ and MARIA LUIZA FELIPPE-BAUER ${ }^{1}$ \\ ${ }^{1}$ Coleção de Ceratopogonidae, Laboratório de Diptera, Instituto Oswaldo \\ Cruz-Fiocruz, Av. Brasil, 4365, 21040-900 Rio de Janeiro, RJ, Brasil \\ ${ }^{2}$ Programa de Pós-Graduação em Zoologia, Museu Nacional/UFRJ, \\ Quinta da Boa Vista, s/n, 20940-040 Rio de Janeiro, RJ, Brasil \\ ${ }^{3}$ Laboratório de Ecologia de Doenças Transmissíveis na Amazônia, Instituto Leônidas e \\ Maria Deane/Fiocruz Amazônia, Rua Teresina, 476, 69057-070 Manaus, AM, Brasil
}

Manuscript received on September 29, 2014; accepted for publication on November 25, 2014

\begin{abstract}
A new species of the reticulatus species group, C. castelloni Santarém and Felippe-Bauer, is described and illustrated based on female specimens from the state of Amazonas, Brazil. A systematic key, wing photographs and table with numerical characters of females and a synopsis of 24 species of the Culicoides reticulatus group are presented. This paper presents further new records for seven species of the reticulatus group.
\end{abstract}

Key words: biting midges, Culicoides reticulatus group, Neotropical Culicoides, new records, new species.

\section{INTRODUCTION}

The reticulatus species group was proposed by Wirth and Blanton (1959) from nine species of the subgenus Oecacta Poey, taking into account the similarity of the pattern of the pale and dark wing spots and others extra alar characters. The fragility of this proposition based on characters also founded in others Culicoides species groups, promoted, in the following years, placements and exclusion of species in the reticulatus species group. Wirth et al. (1988) included in the reticulatus species group 15 species and considered this group out of the subgenus Oecacta and others previously established subgenus of Culicoides.

Correspondence to: Maria Clara Alves Santarém

E-mail: mcalves@ioc.fiocruz.br
This consideration was followed by Borkent and Spinelli (2000, 2007). Recently, Felippe-Bauer et al. (2010) described Culicoides kuripako FelippeBauer from the Brazilian Amazon, and Santarém et al. (2014) redescribed C. reticulatus Lutz and recognized seven species very similar to $C$. reticulatus Lutz on several morphological aspects and included them in the reticulatus species group. Currently, the reticulatus species group is known to contain 23 species well distributed in the neotropics and despite the uncertainty of the monophyly of the group, we maintain this group of species, until further phylogenetic studies are made.

In the present paper, we describe and illustrate a new species from the state of Amazonas, Brazil, 
and provide a key, a table of numerical characters and a diagnosis of the 24 species actually belonging to the reticulatus species group. We also report new neotropical records for seven species of this species group.

The ZooBank Life Science Identifier (LSID) of this publication is: urn:lsid:zoobank. org:pub:AFDE644C-A 5 D 8-484A-BF 91 CABEDA9247A9.

\section{MATERIALS AND METHODS}

The specimens studied were deposited in the following collections:

CCER - Collection of Ceratopogonidae, Instituto Oswaldo Cruz, Rio de Janeiro, Brazil.

ILMD - Laboratory of Biodiversity in Health, Instituto Leônidas e Maria Deane, Manaus, Amazonas, Brazil.

MLP - Entomological Collection, Museu de La Plata, La Plata, Argentina.

MPEG - Invertebrate Collection, Museu Paraense Emílio Goeldi, Pará, Brazil.

The specimens were preserved in alcohol $70 \%$ or slide mounted. The general terminology used is that employed in papers on Culicoides by Wirth and
Blanton $(1959,1973)$ for Panama and the Amazon Basin, the atlas of wing photographs of Neotropical species by Wirth et al. (1988) and the Manual of Central America Diptera (Brown et al. 2009). Meristic informations were updated based on specimens deposited in the above mentioned collections and on data cited in the literature, except for Culicoides macrostigma Wirth and Blanton and C. martinezi Wirth and Blanton whose data were taken from specific literature, because we didn 't obtain specimens for study. All measurements are in micrometres, except those of the wings which are in millimeters.

The new species described herein was collected by CDC light trap in forest areas from Rio Pardo, municipality of Presidente Figueireido, state of Amazonas, Brazil. The specimen was mounted in phenol-balsam in the manner described by Wirth and Marston (1968). The diagnostic characters were illustrated using a camera Moticam 2300 attached to a Nikon Eclipse E-200 microscope, and the figures and plates were prepared using Photoshop GIMP Portable, except C. kuscheli Wirth and Blanton, C. macrostigma and C. martinezi, whose photos of the wings were taken from Wirth et al. (1988) with permission of editors. The new species was deposited in CCER.

KeY TO SPECIES OF reticulatus SPECIES GROUP (PRIMARILY FOR FEMALES)

1. Wing with extensive and interconnected pale spots; $r 3$ with two pale spots 2

- Wing with separated pale spots; $r_{3}$ with three to six pale spots 8

2. Wing with numerous macrotriquia on distal $1 / 2$; legs dark, without pale bands; eyes narrowly separated; halter dark

C. kuscheli Wirth and Blanton

- Wing without macrotrichia or macrotrichia sparsely distributed on distal $1 / 2$; legs with pattern of pale bands; eyes and halter various 3

3. Hind femur dark 4

- Hind femur with subapical pale band 6

4. Hind tibia dark apically; antennal ratio 0.64-0.69; palpal ratio 2.4-3.0; halter dark; [aedeagus with basal arch extending to 0.45 of total length, distal portion with numerous strong spicules; parameres without ventral lobes, distal portion with filamentous tip without fringing spines] ...... C. goeldii Wirth and Blanton 
- Hind tibia pale apically; antennal ratio 0.84-1.05; palpal ratio 2.0-2.4; halter various

5. Second radial cell with pale lumen; antennal ratio $0.84-0.94 ; \mathrm{P} / \mathrm{H}$ ratio $0.60-0.63$; sternite 9 with deep posteromedial excavation; aedeagus with basal arch extending from $1 / 2$ of total length; parameres with large ventral lobes

C. fittkaui Wirth and Blanton

- Second radial cell with dark lumen; antennal ratio 0.96-1.05; P/H ratio 0.71-0.79; sternite 9 with shallow posteromedial excavation; aedeagus with basal arch extending to 0.6 of total length; parameres without ventral lobes

C. guamai Wirth and Blanton

6. $r_{3}$ with inverted L-shaped poststigmatic pale spot, with a dark spot behind second radial cell; $\mathrm{m}_{1}$ with distal pale spot reaching wing margin; $\mathrm{CuA}_{1}$ pale; antennal ratio 1.02-1.34

- $\quad r_{3}$ without inverted L-shaped poststigmatic pale spot; $m_{1}$ with distal pale spot not reaching wing margin; $\mathrm{CuA}_{1}$ dark; antennal ratio 0.84-1.02; [aedeagus with basal arch extending to 0.75 of total length, distal portion flanked by a subapical pair of sclerotized points; parameres without ventral lobes]

C. pifanoi Ortíz

7. $\mathrm{CuA}_{2}$ pale; sternite 9 with ventral membrane not spiculate; aedeagus with distal portion rounded, irregulary ending; parameres with ventral subapical lobes

C. kuripako Felippe-Bauer

- $\mathrm{CuA}_{2}$ dark; sternite 9 with ventral membrane spiculate; aedeagus with distal portion spiculate; parameres without ventral lobes

C. paucienfuscatus Barbosa

8. Hind femur dark

- Hind femur with subapical pale band

9. Eyes broadly separated; $r_{3}$ with six pale spots arranged in two sets of triangles; mid femur dark; costal ratio 0.54 ; [aedeagus with basal arch extending to 0.75 of total length, distal portion with spiculate tip; parameres with large ventral lobes, distal portion with lateral fringe of spicules well developed]

C. martinezi Wirth and Blanton

- Eyes narrowly separated or contiguous; $r_{3}$ with three to five pale spots; mid femur with subapical pale band; costal ratio $0.60-0.74$.

10. $r_{3}$ with five pale spots; $m_{1}$ with three pale spots; antennal ratio $0.72-0.78 ; \mathrm{P} / \mathrm{H}$ ratio $0.66-0.63$; [aedeagus with basal arch extending to $1 / 2$ of total length; parameres with a bladelike ventral lobes, distal portion with lateral fringe with fine spicules]

C. lanei Ortíz

- $\quad r_{3}$ with three to four pale spots; $m_{1}$ with two pale spots ; antennal ratio 0.87-1.97; $\mathrm{P} / \mathrm{H}$ ratio 0.55-1.0 _..... 11

11. Second radial cell $2.5 \mathrm{x}$ longer than first, with pale lumen; antennal ratio $1.97 ; \mathrm{P} / \mathrm{H}$ ratio 0.55 ; mandible with 11 teeth; [sternite 9 with ventral membrane spiculate; aedeagus with basal arch extending to $1 / 2$ of total length; parameres with basal knob bearing an elongate anterior process, without ventral lobes]

C. macrostigma Wirth and Blanton

- Second radial cell shorter, with dark lumen; antennal ratio 0.87-1.09; P/H ratio 0.73-1.0; mandible with 16-18 teeth

12. $r_{3}$ with three pale spots; sensilla coeloconica on flagellomeres $1,(5) 6-8$; eyes narrowly separated; halter dark; palpal ratio 1.9-2.5; [aedeagus with basal arch extending to 0.6 of total length; parameres with well developed ventral lobes, distal portion with lateral fringe of spicules].

C. tavaresi Felippe-Bauer and Wirth 
- $\quad r_{3}$ with four pale spots; sensilla coeloconica on flagellomeres 1,9-13; eyes contiguous; halter pale; palpal ratio 4.2

C. castelloni sp. nov.

13. $\mathrm{r}_{3}$ with five pale spots; $\mathrm{P} / \mathrm{H}$ ratio $0.61-0.87$

- $\quad \mathrm{r}_{3}$ with four pale spots; $\mathrm{P} / \mathrm{H}$ ratio $0.80-1.28$

14. Medium sized species, wing length $0.95-1.12 \mathrm{~mm} ; \mathrm{r}_{3}$ with three pale spots on distal $1 \frac{1}{2}$ of wing; $\mathrm{m}_{1}$ with three pale spots, the distal one reaching wing margin; $\mathrm{P} / \mathrm{H}$ ratio $0.75-0.87$; [aedeagus with basal arch extending to $1 / 2$ of total length, distal portion with a long, slender median lobe and a pair of slender, pointed, lateral lobes; parameres with basal knob bearing a slender anterior process] ……….. C. guyanensis Floch and Abonnenc

- Smaller species, wing length $0.87-0.90 \mathrm{~mm} ; \mathrm{r}_{3}$ with pale spots different from above; $\mathrm{m}_{1}$ with two pale spots, the distal one not reaching wing margin; $\mathrm{P} / \mathrm{H}$ ratio $0.61-0.70$

15. $r_{3}$ with five pale spots in the proximal $\frac{1}{2}$ of cell; halter pale; antennal ratio $0.72-0.76$; mandible with 18 teeth; [aedeagus with basal arch extending to 0.3 of total length; parameres without ventral lobes, distal portion curved, apex flattened]

C. aureus Ortíz

- $r_{3}$ with pale spots different from above; halter dark; antennal ratio 1.05-1.10; mandible with 12 teeth

C. forattinii Ortíz

16. $\mathrm{r}_{3}$ with pale spots in the proximal $1 / 2$ of cell, crossvein $\mathrm{R}-\mathrm{M}$ dark; $\mathrm{CuA}_{2}$ with pale apex; mandible with 12 teeth; [aedeagus with basal arch extending to 0.8 of total length; parameres stem sinuous, distal portion with lateral fringe with four or five spicules]

C. lyrinotatus Wirth and Blanton

- $\quad \mathrm{r}_{3}$ with pale spots different from above, crossvein $\mathrm{R}-\mathrm{M}$ pale, $\mathrm{CuA}_{2}$ with dark apex; mandible with 16-25 teeth

17. Third palpal segment with multiple shallow, irregular sensory pits on ventral, dorsal and lateral sides of segment; proboscis moderately long, $\mathrm{P} / \mathrm{H}$ ratio $0.80-0.94$; unequal sized spermathecae C. irregularis Santarém, Felippe-Bauer and Castellón

- Third palpal segment with one or two sensory pits; proboscis and spermathecae various 18

18. Third palpal segment with two well defined sensory pits on distal $2 / 3$ of segment, the basal one on ventral side and the distal one on lateral side; mandible with 21 teeth; [male tergite 9 with very shortandblunt apicolateral processes, with distinctly posteromedial notch; parameres swollen in median portion ending in ventral lobes; basal arch of aedeagus extending to $2 / 3$ of total length] .......... C. diplus Santarém and Felippe-Bauer

- Third palpal segment with one sensory pit on ventral side; mandible teeth various

19. Sensory pit deep, round and opening in a small pore; proboscis moderately long, $\mathrm{P} / \mathrm{H}$ ratio $0.86-0.95$; mandible with 16 teeth C. profundus Santarém, Felippe-Bauer and Trindade

- Sensory pit shallow; proboscis long; P/H ratio 1.0-1.28; mandible with 19-25 teeth 20

20. Large species, wing length $1.30 \mathrm{~mm}$; eyes separated by $1 / 2$ ommatidium; [parameres sinuous without ventral lobes; basal arch of aedeagus extending to $1 / 2$ of total length]

C reticulatus Lutz

- Smaller species, wing length 0.80-1.16; eyes narrowly separated by $<1 / 2$ ommatidium 21

21. Third palpal segment rhomboidal, greatly swollen at middle length; sensory pit irregular occupying the distal $1 / 2$ of segment

C. rhombus Santarém, Felippe-Bauer and Castellón 
- Third palpal segment different from above, slightly swollen at middle length; sensory pit regular, round occupying the middle portion of segment

22. Wing length 1.03-1.16; a single pale spot over crossvein R-M ….. C. fluminensis Santarém and Felippe-Bauer

- Wing length 0.80-0.95; pale spot over crossvein R-M subdivided

23. Sensory pit small and round, with contours on distal $1 / 2$ not well-defined; P.R. 2.0-2.7; mandible with 19 teeth; two slightly unequal ovoid spermathecae.

C. pseudoreticulatus Santarém, Felippe-Bauer and Castellón

- Sensory pit large and oval, with defined contours; P.R. 2.6-3.2; mandible with 24 teeth; two unequal ovoid spermathecae

C. amazonicus Santarém, Felippe-Bauer and Trindade

\section{C. amazonicus Santarém, Felippe-Bauer and} Trindade (Fig. 1, Table I)

C. amazonicus Santarém et al. 2014: 259 (female; Brazil (Pará); figs.)

Diagnosis: Female: $r_{3}$ with four pale spots; scutum with four median anterior yellowish spots arranged as a leaf clover; $m_{1}$ with two pale spots, the distal one far from wing margin; palpus 3rd segment swollen, with large, shallow, oval sensory pit on middle of segment; PR 2.6-3.2; long proboscis, $\mathrm{P} / \mathrm{H}$ ratio 1.03-1.16; mandible with 24 teeth; two unequal spermathecae. Male: unknown.

Distribution: Brazil (Pará).

\section{C. aureus Ortiz (Fig. 2, Table I)}

C. aureus Ortiz 1951a: 585 (male; Venezuela); Fox 1955: 228 (Panama; miyamotoi syn.); Forattini 1957: 478 (in neotropical catalog; figs.; distrib.); Wirth and Blanton 1959: 447 (redescrip.; male, female; figs.; Panama records; distrib.); Aitken et al. 1975: 116 (Trinidad record; wing fig.; distrib.); Spinelli and Wirth 1986: 59 (Brazil (Amazonas) and Bolivia records; key; wing fig.); Wirth et al. 1988: 38 (Atlas; wing fig.; distrib.); Borkent and Wirth 1997: 62 (in catalog); Ronderos and Spinelli 1998: 81 (Argentina and Paraguay records); Borkent and Spinelli 2000: 41 (in catalog; distrib.); Ronderos et al. 2003: 19 (bionomics); Borkent and Spinelli 2007: 74 (in catalog; distrib.); Borkent 2014: 76 (in catalog).

C. miyamotoi Wirth and Blanton 1953: 231 (female, male; Panama).
Diagnosis: Female: $r_{3}$ with five pale spots in the proximal $1 / 2$ of cell; $\mathrm{m}_{1}$ with two pale spots, the distal one far from wing margin; AR 0.720.76; proboscis short, $\mathrm{P} / \mathrm{H}$ ratio 0.61-0.70. Male: sternite 9 with slightly perceptible posteromedial excavation; aedeagus with basal arch extending to 0.3 of total length; parameres without ventral lobes, distal portion curved, apex flattened.

New record: One female, BRAZIL, Goiás, Caldas Novas, $17^{\circ} 44^{\prime} \mathrm{S} 48^{\circ} 37^{\prime} \mathrm{W}$, biting human, R. Mello col., XII.1997 (CCER).

Distribution: Panama, Venezuela, Brazil (Amazonas, Goiás), Bolivia, Argentina and Paraguay.

\section{C. castelloni Santarém and Felippe-Bauer,} sp.nov. (Figs. 3, 25-30, Table I)

ZooBank Life Science Identifier (LSID) urn:1sid:zoobank.org:act:6899BA1A-16BD-4D0B9997-BD1602623756.

Type material: Holotype female, BRAZIL, Amazonas, Presidente Figueiredo, Rio Pardo, $1^{\circ} 48^{\prime}$ S $60^{\circ} 19^{\prime} \mathrm{W}, \mathrm{CDC}$ light trap, forest, F. Pessoa col. 17-18.VIII.2010 (CCER).

Etymology: This species is named in honor of Dr. Eloy Guillermo Castellón for his contributions on Culicoides studies in the Brazilian Amazon Region.

Diagnosis: Only species of the reticulatus species group with sensilla coeloconica on flagellomeres 1,9-13; eyes contiguous; third palpal segment fusiform, long, with a rudimentary sensory pit laterally; PR 4.2; wing with large, separated and 
rounded pale spots; $r_{3}$ with four pale spots; $m_{1}$ with two pale spots, the distal one far from wing margin; hind femur dark; hind tibial comb with six spines.

Description: Female. Head. Brown. Eyes bare, contiguous by a distance of two ommatidia (Fig. 25). Antenna (Fig. 29) pale brown; pedicel brown; flagellomeres paler on proximal $1 / 2$; antennal ratio $1.09(\mathrm{n}=1)$; sensilla coeloconica on flagellomeres 1,9-13, three on 1, one on 9-12, two on 13. Palpus (Fig. 28) brown; third segment fusiform, long, with a rudimentary sensory pit laterally; palpal ratio 4.2 $(\mathrm{n}=1)$. Proboscis moderately long; $\mathrm{P} / \mathrm{H}$ ratio $1.0(\mathrm{n}=$ 1); mandible with $18(\mathrm{n}=1)$ teeth.

Thorax. Dark brown (Fig. 27). Prominent pattern of yellowish patches well defined; pale humeral depressions present. Scutum with two parallel, longitudinal, admedian pale spots, anterior to the prescutellar depression; lateral portion dark; pale prescutellar depressions present; scutellum and postscutellum brown. Wing (Fig. 3) with contrasting pattern of pale spots large, separated and rounded: second radial cell including dark spot; pale spot over R-M extending from $M_{1}$ to the costal margin; $r_{3}$ with four pale spots: first, between the second radial cell and $\mathrm{M}_{1}$; second, poststigmatic, extending behind second radial cell, abutting wing margin; third, in the middle of cell; fourth, distal pale spot slightly reaching wing margin; $\mathrm{m}_{1}$ with two pale spots, the distal one far from wing margin and similar to proximal one; $\mathrm{m}_{2}$ with four pale spots: one proximal, near $\mathrm{CuA}$, second and third between the medial and mediocubital forks, and a distal one not reaching wing margin; cua 1 with a pale spot in the middle of cell; anal cell with a basal pale area and two distal pale spots, one near mediocubital fork, remaining one near wing margin; wing base with a pale spot on $\mathrm{M} ; \mathrm{M}_{1}, \mathrm{M}_{2}$ and $\mathrm{CuA}_{1}$ with pale apex; macrotrichia scarce; wing length 0.83 (n =1) $\mathrm{mm}$; breadth $0.40(\mathrm{n}=1) \mathrm{mm}$; costal ratio $0.64(\mathrm{n}=1)$. Halter pale. Legs (Fig. 30) brown; fore and mid femora with subapical pale bands; tibiae with subbasal pale bands; hind tibia pale apically; hind tibial comb with six spines, the second nearest the spur longest.

Abdomen. Brown. Two unequal ovoid spermathecae (Fig. 26), measuring $60 \mu \mathrm{m}$ by 45 $\mu \mathrm{m}$ and $37.5 \mu \mathrm{m}$ by $37 \mu \mathrm{m}(\mathrm{n}=1)$, with short sclerotized ducts $(2.5 \mu \mathrm{m})$. Short, rudimentary third spermathecae present $(7.5 \mu \mathrm{m})$.

Male. Unknown

Distribution and bionomics: This species is restricted to the state of Amazonas. It is associated with forest areas.

Taxonomic notes: Culicoides castelloni is the only species of reticulatus species group with sensilla coeloconica on flagellomeres 1, 9-13 and a tibial comb with six spines (sensilla coeloconica 1,5-8 or 1,6-8 and tibial comb with 4-5 spines in other species of the group). It has a long third palpal segment (PR 4.2) with a small, rudimentary sensory pit (PR 1.6-3.2 with variable sensory pit, in other species of the group). The female of $C$. castelloni has similar wing pattern to $C$. reticulatus Lutz, but it can be distinguished by the characters described above and by the presence of two parallel, longitudinal, admedian pale spots, anterior to the prescutellar depression (with four median anterior yellowish spots arranged as a leaf clover in C. reticulatus Lutz).

C. diplus Santarém and Felippe-Bauer (Fig. 4, Table I)

C. diplus Santarém et al. 2014: 261 (male, female; Panama and Colombia; figs.)

C. reticulatus: Wirth and Blanton 1959: 393; Wirth and Blanton 1973: 446 (distrib. in part, at least specimens from Colombia and Panama); Wirth et al. 1988: 42 (in Atlas; fig. wing; distrib. in part, at least specimens from Colombia and Panama); Borkent and Spinelli 2000: 41 (in catalog; distrib. in part, at least specimens from Colombia and Panama); Borkent and Spinelli 2007: 74 (in catalog; distrib. in part, at least specimens from Colombia and Panama). 
Diagnosis: Female: $r_{3}$ with four pale spots; $\mathrm{m}_{1}$ with two pale spots, the distal one far from wing margin; scuttum with four median anterior yellowish spots arranged as a leaf clover; 3rd segment of palpus with two well-defined sensory pits on distal $2 / 3$ of the segment, the basal one ventrally and the distal one laterally; PR 2.5-2.8. Male: tergite 9 long, tapering, with very short and blunt apicolateral processes, with distinct posteromedial notch; parameres stem sinuous and swollen in median portion ending in ventral lobes; basal arch of aedeagus extending 2/3 of total length.

Distribution: Panama and Colombia

C. fittkaui Wirth and Blanton (Fig. 5, Table I)

C. fittkaui Wirth and Blanton 1973: 432 (male, female; Brazil (Pará); figs.); Wirth et al. 1988: 38 (Atlas; wing fig.; distrib.); Borkent and Wirth 1997: 67 (in catalog); Borkent and Spinelli 2000: 41 (in catalog; distrib.); Borkent and Spinelli 2007: 74 (in catalog; distrib.); Borkent 2014: 82 (in catalog).

Diagnosis: Female: Pale spots of the wing interconnected; $r_{3}$ with two pale spots; second radial cell with pale lumen; $m_{1}$ with two pale spots, the distal one reaching wing margin; eyes nearly contiguous; hind femur dark; proboscis short, $\mathrm{P} / \mathrm{H}$ ratio $0.60-0.63$. Male: sternite 9 with deep posteromedial excavation; aedeagus with basal arch extending from $1 / 2$ of total length; parameres with large ventral lobes, apical portion with lateral fringe of spicules.

Distribution: Brazil (Pará).

Taxonomic notes: Wirth and Blanton (1973) described and illustrated the eyes of this species as contiguous in lower portion. The authors not mentioned the presence of pale spots in hind femur, but in the figure $8 \mathrm{~g}$, the hind femur is illustrated with large subapical pale band. Analyzing the female holotype deposited in ILMD, we observed that the eyes are narrowly separated in all extension and the hind femur is entirely dark, corroborating the original description.

\section{C. fluminensis Santarém and Felippe-Bauer} (Fig. 6, Table I)

C. fluminensis Santarém et al. 2014: 263 (female; Brazil (Rio de Janeiro); figs.)

C. reticulatus Lutz 1913: 49 (female; Brazil (Rio de Janeiro, São Paulo and Bahia); fig. wing, male, larva; bionomy, larva in crab holes in mangrove edge; in part material from Rio de Janeiro); Forattini 1957: 432 (in neotropical catalog; figs.; distrib. in part specimens from Rio de Janeiro); Wirth and Blanton 1973: 446 (distrib. in part material from Rio de Janeiro); Borkent and Spinelli 2000: 41 (in catalog; distrib. in part material from Rio de Janeiro); Borkent and Spinelli 2007: 74 (in catalog; distrib. in part material from Rio de Janeiro).

Diagnosis: Female: $r_{3}$ with four pale spots; $m_{1}$ with two pale spots, the distal one far from wing margin; single pale spot over R-M; anal cell with two distal pale spots, one near mediocubital fork and other not reaching wing margin; scutum with four median anterior yellowish spots arranged as a leaf clover; $3^{\text {rd }}$ segment of palpus with a small, shallow, rounded, sensory pit in middle portion; PR 2.6-3.2; long proboscis; two unequal spermathecae. Male: Unknown

Distribution: Brazil (Rio de Janeiro)

C. forattinii Ortiz (Fig. 7, Table I)

C. forattinii Ortiz 1961: 211 (female; Venezuela); Wirth et al. 1988: 38 (Atlas; wing fig.; distrib.); Borkent and Wirth 1997: 68 (in catalog); Borkent and Spinelli 2000: 41 (in catalog; distrib.); Borkent and Spinelli 2007: 74 (in catalog; distrib.); Borkent 2014: 83 (in catalog).

Diagnosis: Female: $r_{3}$ with five pale spots, the distal one reaching wing margin; $\mathrm{m}_{1}$ with two pale spots, the distal one far from wing margin; halter dark; AR 1.05-1.10; proboscis short, $\mathrm{P} / \mathrm{H}$ ratio 0.68 ; mandible with 12 teeth. Male: unknown

New records: One female, BRAZIL, Roraima, Maracá, 325’N 6140'W, “mata 1m”, CDC light trap, E. Castellón and S. Gomes cols, 21.V.1987 (ILMD); 1 
female, same data except 26.V.1987 (ILMD); 1 female, same data except 25.VI.1987 (ILMD); 1 female, same data except 30.VII.1987 (ILMD); 1 female, same data except 16.VI.1987 (CCER); 1 female, same data except 22.VI.1987 (CCER).

Distribution: Venezuela and Brazil (Roraima).

C. goeldii Wirth and Blanton (Fig. 8, Table I)

C. goeldii Wirth and Blanton 1973: 437 (male, female; Brazil (Pará); figs.); Wirth et al. 1988: 41 (Atlas; wing fig.; distrib.); Borkent and Wirth 1997: 69 (in catalog); Borkent and Spinelli 2000: 41 (in catalog; distrib.); Borkent and Spinelli 2007: 74 (in catalog; distrib.); Borkent 2014: 84 (in catalog).

Diagnosis: Female: Pale spots of the wing interconnected; $r_{3}$ with two pale spot and a dark spot behind second radial cell; $\mathrm{m}_{1}$ with two pale spots, the distal one reaching wing margin; halter dark; hind femur dark, hind tibia dark apically; AR 0.64-0.69; proboscis short, $\mathrm{P} / \mathrm{H}$ ratio 0.690.75. Male: sternite 9 with shallow posteromedial excavation; aedeagus with basal arch extending to 0.45 of total length, distal portion with numerous strong spicules; parameres swollen in median portion, without ventral lobes, distal portion with filamentous tip without fringing spines.

Distribution: Brazil (Pará).

C. guamai Wirth and Blanton (Fig. 9, Table I)

C. guamai Wirth and Blanton 1973: 438 (male, female; Brazil (Pará); figs.); Wirth et al. 1988: 40 (Atlas; wing fig.; distrib.); Borkent and Wirth 1997: 69 (in catalog); Borkent and Spinelli 2000: 41 (in catalog; distrib.); Borkent and Spinelli 2007: 74 (in catalog; distrib.); Borkent 2014: 85 (in catalog).

Diagnosis: Female: Pale spots of the wing interconnected; $r_{3}$ with two pale spots; $m_{1}$ with two pale spots, the distal one reaching wing margin; second radial cell short, with dark lumen; hind femur dark; proboscis short, $\mathrm{P} / \mathrm{H}$ ratio 0.71 0.79 . Male: sternite 9 with shallow posteromedial excavation; aedeagus with basal arch extending to 0.6 of total length; parameres with a strong ventral swelling on proximal portion of stem, distal portion with filamentous tip with fringing spines.

Distribution: Brazil (Pará).

C. guyanensis Floch and Abonnenc (Fig. 10, Table I) C. guyanensis Floch and Abonnenc 1942: 4 (male, female; Guyana); Barbosa 1947: 5 (key; recifensis and stubalensis syn.; fig.); Macfie 1948: 69 (key); Ortiz 1950a: 463 (distrib.); Ortiz 1951b: 9 (key); Fox 1955: 240 (distrib.); Forattini and Rabello 1956: 43 (descrip. pupae, larvae); Forattini 1957: 466 (in neotropical catalog; pupae, larvae; figs.; distrib.); Wirth and Blanton 1959: 370 (key; redescrip.; figs.; Panama records; distrib.); Aitken et al. 1975: 128 (key; wing fig.; distrib.); Spinelli and Wirth 1986: 54 (key; wing fig.); Wirth et al. 1988: 40 (Atlas; wing fig.; distrib.); Borkent and Wirth 1997: 69 (in catalog); Silva and Rebêlo 1999: 169 (Brazil (Maranhão) records); Borkent and Spinelli 2000: 41 (in catalog; distrib.); Laender et al. 2004: 149 (Brazil (Minas Gerais and Rio de Janeiro) records); Borkent and Spinelli 2007: 74 (in catalog; distrib.); Borkent 2014: 85 (in catalog).

C. recifensis Barbosa 1943: 263 (Brazil).

C. stubalensis Fox 1946: 254 (Trinidad and Tobago).

Diagnosis: Female: $r_{3}$ with five pale spots, the distal three distributed as a triangle; $\mathrm{m}_{1}$ with three pale spots, the distal one reaching wing margin; proboscis short, $\mathrm{P} / \mathrm{H}$ ratio $0.75-0.87$; sensilla coeloconica on flagellomeres 1,4-8. Male: sternite 9 with shallow posteromedial excavation; aedeagus with basal arch extending to $1 / 2$ of total length, distal portion with a long, slender median lobe and a pair of slender, pointed, lateral lobes; parameres with basal knob bearing a slender anterior process, stem stout and tapering in a slender simple tip.

New records: One male, HONDURAS, Barbareta Island, $16^{\circ} 26^{\prime} \mathrm{N} 86^{\circ} 07^{\prime} \mathrm{W}$, light trap, G.M. Stokes col, 23.I.1971 (MLP); BRAZIL: 3 females, Amapá, National Park, Cabo Orange, $4^{\circ} 24^{\prime} \mathrm{N} 51^{\circ} 33 \mathrm{~W}$, mangrove, biting human, Santos col, 12.IV.2005 (MPEG); 1 female, Ceará, Barroquinha, $3^{\circ} 01^{\prime} \mathrm{S} 41^{\circ} 08^{\prime} \mathrm{W}, \mathrm{CDC}$ light trap, 
R.A. Silva col, 06-07.IX.2010 (CCER); 1 female, Ceará, São Gonçalo do Amarante, Siupé, 3³2'S $38^{\circ} 56^{\prime} \mathrm{W}$ CDC light trap (CCER); 2 females, same data except Horizonte, Timbaúba, 46'S 38²9’ W, (CCER); 56 females, same data except Aracati, Córrego da Inveja, 4³3'S 37²6'W (CCER); 5 females, same data except Itapipoca, Vila Jardim, $3^{\circ} 29^{\prime}$ 'S 39³5'W (CCER); 381 specimens, same data except Fortaleza, 33's 38³1W (CCER); 655 specimens, same data except Aquiraz, Tupuiu, 353'S 38²3'W (CCER); 31 females, same data except "biting human" (CCER); 2 males, Espírito Santo, Vitória, Goiabeira, 20¹7’S 40¹7’ W, CDC, I.S. Pinto col, 02.II.2007 (CCER).

Distribution: Honduras, Panama, Venezuela, Trinidad and Tobago, Guyana and Brazil (Amapá, Pará, Ceará, Maranhão, Pernambuco, Espírito Santo, Minas Gerais, Rio de Janeiro and São Paulo).

\section{C. irregularis Santarém, Felippe-Bauer and} Castellón (Fig. 11, Table I)

C. irregularis Santarém et al. 2014: 265 (female, Brazil (Amazonas and Roraima; figs.)

Diagnosis: Female: $r_{3}$ with four pale spots; $m_{1}$ with two pale spots, the distal one far from wing margin; scutum with four median anterior yellowish spots arranged as a leaf clover; palpus $3^{\text {rd }}$ segment with a multiple, shallow, irregular sensory pit; PR 2.0-2.9; moderately long proboscis, $\mathrm{P} / \mathrm{H}$ ratio 0.80 0.94; mandible with 16 teeth; two unequal ovoid spermathecae. Male: unknown

Distribution: Brazil (Amazonas and Roraima)

\section{C. kuripako Felippe-Bauer (Fig. 12, Table I)}

C. kuripako Felippe-Bauer et al. 2010: 863 (male, female; Brazil (Amazonas and Pará); figs.); Borkent 2014: 88 (in catalog).

Diagnosis: Female: Pale spots of the wing interconnected; $r_{3}$ with two pale spots, postigmatic pale spot inverted L-shaped, isolating a dark spot behind second radial cell; $\mathrm{m}_{1}$ with two pale spots, the distal one reaching wing margin; $\mathrm{CuA}_{1}$ and $\mathrm{CuA}_{2}$ pale. Male: sternite 9 with deep posteromedial excavation; aedeagus with basal arch extending to $1 / 2$ of total length; parameres with ventral lobes, distal portion with lateral fringe of spicules.

Distribuição: Brazil (Amazonas and Pará).

C. kuscheli Wirth and Blanton (Fig. 13, Table I)

C. kuscheli Wirth and Blanton 1978: 236 (female; Chile; figs.; distrib.); Spinelli and Wirth 1986: 53 (key; wing fig.); Wirth et al. 1988: 40 (Atlas; wing fig.; distrib.); Borkent and Wirth 1997: 72 (in catalog); Borkent and Spinelli 2000: 41 (in catalog; distrib.); Borkent and Spinelli 2007: 74 (in catalog; distrib.); Borkent 2014: 88 (in catalog).

Diagnosis: Female: wing moderately hairy on distal $1 / 2 ; r_{3}$ with two pale spots; $m_{1}$ with two pale areas, the distal one not reaching wing margin; legs dark, without pattern of pale bands; AR 0.88; proboscis short, $\mathrm{P} / \mathrm{H}$ ratio 0.88 ; mandible with 11 12 teeth. Male: unknown

Distribution: Chile.

\section{C. lanei Ortiz (Fig. 14, Table I)}

C. lanei Ortiz 1950b: 431 (male; Panama; distrib.); Ortiz 1951a: 577 (male; figs.); Khalaf 1954: 37 (in list); Fox 1955: 244 (distrib.); Forattini 1957: 472 (in neotropical catalog; figs.; distrib.); Wirth and Blanton 1959: 374 (redescript.; male and female; figs.; Panama records; distrib.); Wirth and Blanton 1973: 441 (key; Brazil (Pará) records; distrib.); Aitken et al. 1975: 131 (key; wing fig.; Trinidad records; distrib.); Wirth et al. 1988: 40 (Atlas; wing fig.; distrib.); Borkent and Wirth 1997: 72 (in catalog); Borkent and Spinelli 2000: 41 (in catalog; distrib.); Borkent and Spinelli 2007: 74 (in catalog; distrib.); Borkent 2014: 89 (in catalog).

Diagnosis: Female: $r_{3}$ with five pale spots; $m_{1}$ with three pale spots, the distal one near wing margin; hind femur dark, hind tibia dark apically; AR 0.720.78; proboscis short, $\mathrm{P} / \mathrm{H}$ ratio 0.63-0.66. Male: sternite 9 with shallow posteromedial excavation; aedeagus with basal arch extending to $1 / 2$ of total length; parameres with bladelike ventral lobes, distal portion with lateral fringe with fine spicules. 

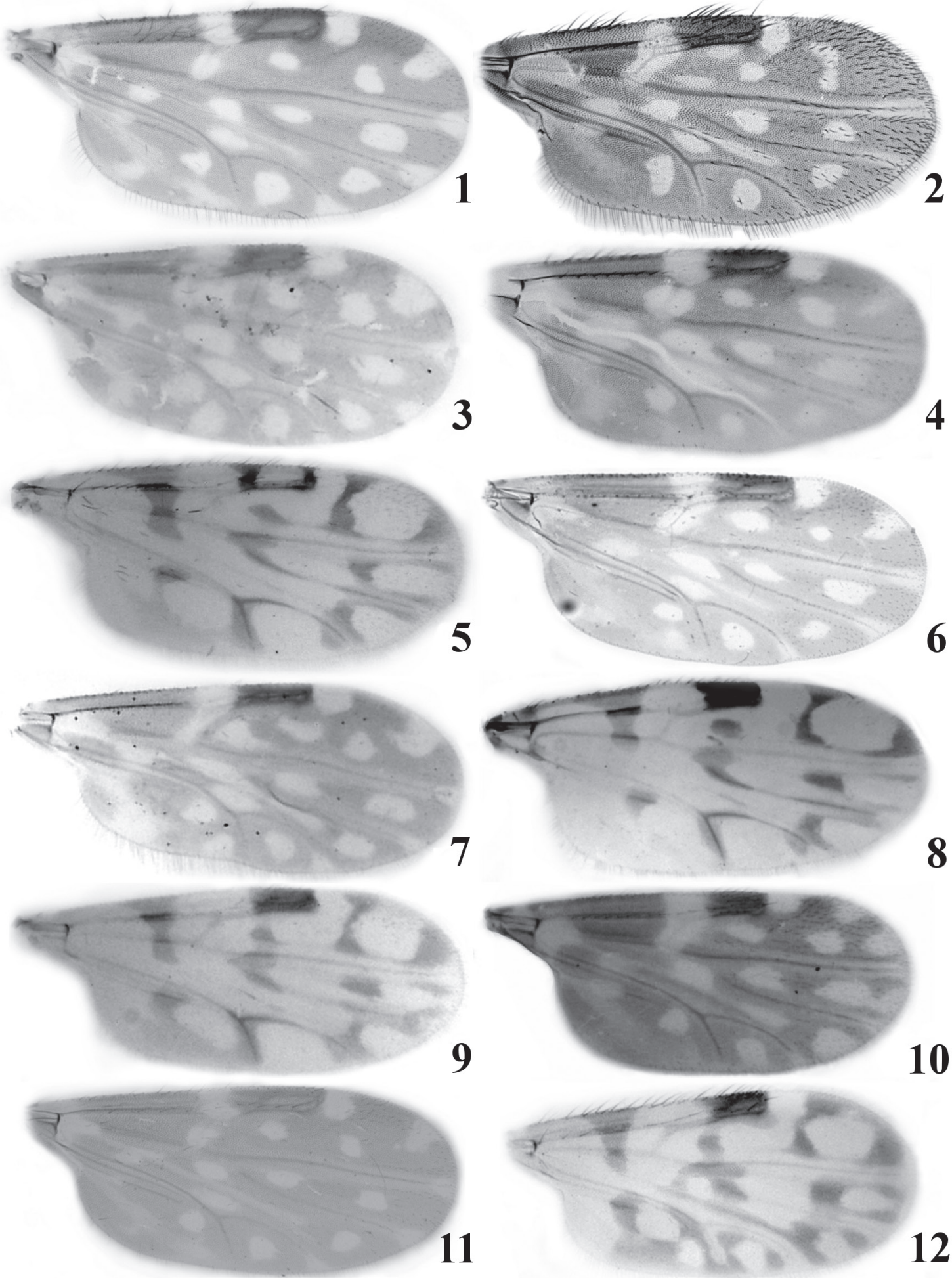

Figures 1-12 - Wing photograph of Culicoides reticulatus species group. 1. C. amazonicus. 2. C. aureus. 3. C. castelloni sp.nov. 4. C. diplus. 5. C. fittkaui. 6. C. fluminensis. 7. C. forattinii. 8. C. goeldii. 9. C. guamai. 10. C. guyanensis. 11. C. irregularis. 12. C. kuripako. 
TABLE I

Numerical characters of females of

Culicoides reticulatus species group.

\begin{tabular}{|c|c|c|c|c|c|c|c|}
\hline Species $^{a}$ & $\begin{array}{l}\text { Wing } \\
\text { length }\end{array}$ & Costal ratio & $\begin{array}{l}\text { Antennal } \\
\text { ratio }\end{array}$ & $\begin{array}{c}\text { Palpal } \\
\text { ratio }\end{array}$ & $\mathrm{P} / \mathrm{H}$ ratio & Sensillapattern & $\begin{array}{c}\text { Mandible } \\
\text { teeth }\end{array}$ \\
\hline C. amazonicus & $\begin{array}{c}0.87-0.95 \\
(0.92)\end{array}$ & $\begin{array}{c}0.62-0.66 \\
(0.64)\end{array}$ & $\begin{array}{c}0.98-1.04 \\
(1.0)\end{array}$ & $\begin{array}{c}2.6-3.2 \\
(2.8)\end{array}$ & $\begin{array}{c}1.03-1.16 \\
(1.11)\end{array}$ & $1,6-8$ & 24 \\
\hline C. aureus & $\begin{array}{c}0.88-0.89 \\
(0.88)\end{array}$ & $\begin{array}{c}0.62-0.63 \\
(0.62)\end{array}$ & $\begin{array}{c}0.72-0.76 \\
(0.74)\end{array}$ & $\begin{array}{c}2.0-2.1 \\
(2.0)\end{array}$ & $\begin{array}{c}0.61-0.70 \\
(0.65)\end{array}$ & $1,5-8$ & 18 \\
\hline C. castelloni & 0.83 & 0.64 & 1.09 & 4.2 & 1.0 & $1,9-13$ & 18 \\
\hline C. diplus & $\begin{array}{c}0.94-0.98 \\
\quad(0.96)\end{array}$ & 0.66 & $\begin{array}{c}1.04-1.13 \\
(1.08)\end{array}$ & $\begin{array}{c}2.5-2.8 \\
(2.7)\end{array}$ & $\begin{array}{c}1.0-1.05 \\
(1.02)\end{array}$ & $1,6-8$ & 21 \\
\hline C. fittkaui & 1.15 & $\begin{array}{c}0.61-0.69 \\
(0.65)\end{array}$ & $\begin{array}{c}0.84-0.94 \\
(0.89)\end{array}$ & $\begin{array}{c}2.2-2.4 \\
(2.3)\end{array}$ & $\begin{array}{c}0.60-0.63 \\
(0.61)\end{array}$ & $1,6-8$ & 18 \\
\hline C. fluminensis & $\begin{array}{c}1.03-1.16 \\
(1.08)\end{array}$ & $\begin{array}{c}0.63-0.66 \\
(0.65)\end{array}$ & $\begin{array}{c}0.95-1.12 \\
(1.03)\end{array}$ & $\begin{array}{c}2.6-3.2 \\
(2.9)\end{array}$ & $\begin{array}{c}1.05-1.18 \\
(1.14)\end{array}$ & $1,6-8$ & 20 \\
\hline C. forattinii & $\begin{array}{c}0.87-0.90 \\
(0.88)\end{array}$ & $\begin{array}{c}0.60-0.61 \\
(0.60)\end{array}$ & $\begin{array}{c}1.05-1.10 \\
(1.1)\end{array}$ & $\begin{array}{c}1.9-2.0 \\
(1.9)\end{array}$ & 0.68 & $1,5-8$ & 12 \\
\hline C. goeldii & $\begin{array}{c}1.02-1.24 \\
(1.18)\end{array}$ & 0.58 & $\begin{array}{c}0.64-0.69 \\
(0.67)\end{array}$ & $\begin{array}{c}2.4-3.0 \\
(2.8)\end{array}$ & $\begin{array}{c}0.69-0.75 \\
(0.73)\end{array}$ & $1,5-8$ & 18 \\
\hline C. guamai & $\begin{array}{c}1.0-1.12 \\
(1.06)\end{array}$ & $\begin{array}{c}0.61-0.62 \\
(0.62)\end{array}$ & $\begin{array}{c}0.96-1.05 \\
(0.99)\end{array}$ & $\begin{array}{c}2.0-2.3 \\
(2.1)\end{array}$ & $\begin{array}{c}0.71-0.79 \\
(0.74)\end{array}$ & $1,6-8$ & 16 \\
\hline C. guyanensis & $\begin{array}{c}0.95-1.12 \\
(1.06)\end{array}$ & $\begin{array}{c}0.58-0.66 \\
(0.62)\end{array}$ & $\begin{array}{c}1.0-1.05 \\
(1.02)\end{array}$ & $\begin{array}{c}1.9-2.4 \\
(2.1)\end{array}$ & $\begin{array}{c}0.75-0.87 \\
(0.79)\end{array}$ & $1,4-8$ & 15 \\
\hline C. irregularis & $\begin{array}{c}0.85-1.05 \\
(0.98)\end{array}$ & $\begin{array}{c}0.58-0.68 \\
(0.65)\end{array}$ & $\begin{array}{c}1.04-1.25 \\
(1.12)\end{array}$ & $\begin{array}{c}2.0-2.9 \\
(2.6)\end{array}$ & $\begin{array}{c}0.80-0.94 \\
(0.84)\end{array}$ & $1,6-8$ & 16 \\
\hline C. kuscheli & 1.21 & 0.57 & 0.88 & 2.1 & 0.88 & $1,5-8$ & $11-12$ \\
\hline C. lanei & $\begin{array}{c}0.9-1.12 \\
(1.0)\end{array}$ & $\begin{array}{c}0.63-0.68 \\
(0.67)\end{array}$ & $\begin{array}{c}0.72-0.78 \\
(0.75)\end{array}$ & $\begin{array}{c}1.6-2.1 \\
(2.0)\end{array}$ & $\begin{array}{c}0.63-0.66 \\
(0.65)\end{array}$ & $1,5-8$ & $12-14$ \\
\hline C. lyrinotatus & $\begin{array}{c}1.12-1.22 \\
(1.1)\end{array}$ & $\begin{array}{c}0.67-0.71 \\
(0.69)\end{array}$ & 1.01 & 2.3 & 0.83 & $1,6-8$ & 12 \\
\hline C. kuripako & $\begin{array}{c}0.89-1.05 \\
(0.98)\end{array}$ & $\begin{array}{c}0.60-0.62 \\
(0.61)\end{array}$ & $\begin{array}{c}1.12-1.23 \\
(1.16)\end{array}$ & $\begin{array}{c}2.2-2.7 \\
(2.5)\end{array}$ & $\begin{array}{c}0.81-0.94 \\
(0.87)\end{array}$ & $1,5-8$ & $11-13$ \\
\hline C. macrostigma & $\begin{array}{c}0.83-0.96 \\
(0.91)\end{array}$ & $\begin{array}{c}0.70-0.74 \\
(0.71)\end{array}$ & 1.97 & $\begin{array}{c}1.6-2.0 \\
(1.8)\end{array}$ & 0.55 & $1,6-8$ & 11 \\
\hline C. martinezi & 0.81 & 0.54 & 1.06 & 2.9 & 0.97 & $1,5-8$ & 15 \\
\hline C. paucienfuscatus & $\begin{array}{c}0.84-1.16 \\
\quad(1.02)\end{array}$ & $\begin{array}{c}0.60-0.66 \\
(0.63)\end{array}$ & $\begin{array}{c}1.02-1.34 \\
(1.18)\end{array}$ & $\begin{array}{c}1.8-2.7 \\
(2.2)\end{array}$ & $\begin{array}{c}0.68- \\
0.80(0.73)\end{array}$ & $1,5-8$ & $11-15$ \\
\hline C. pifanoi & $\begin{array}{c}0.73-0.89 \\
(0.79)\end{array}$ & $\begin{array}{c}0.56-0.60 \\
(0.57)\end{array}$ & $\begin{array}{c}0.84-1.02 \\
(0.91)\end{array}$ & $\begin{array}{c}1.6-2.2 \\
(1.9)\end{array}$ & $\begin{array}{c}0.69-0.93 \\
(0.77)\end{array}$ & $1,5-8$ & $12-15$ \\
\hline C. profundus & $\begin{array}{c}0.82-0.97 \\
(0.93)\end{array}$ & $\begin{array}{c}0.60-0.67 \\
(0.64)\end{array}$ & $\begin{array}{c}1.02-1.18 \\
(1.10)\end{array}$ & $\begin{array}{c}1.8-2.4 \\
(2.1)\end{array}$ & $\begin{array}{c}0.86-0.95 \\
(0,90)\end{array}$ & $1,(5) 6-8$ & 16 \\
\hline C. pseudoreticulatus & $\begin{array}{c}0.80-0.90 \\
(0.85)\end{array}$ & $\begin{array}{c}0.61-0.66 \\
(0.63)\end{array}$ & $\begin{array}{c}0.98-1.04 \\
(0.98)\end{array}$ & $\begin{array}{c}2.0-2.7 \\
(2.4)\end{array}$ & $\begin{array}{c}1.0-1.06 \\
(1.03)\end{array}$ & $1,6-8$ & 19 \\
\hline C. reticulatus & 1.3 & 0.64 & $\begin{array}{c}1.0-1.04 \\
(1.02)\end{array}$ & $\begin{array}{c}2.6-3.0 \\
(2.8)\end{array}$ & $\begin{array}{c}1.14-1.17 \\
(1.16)\end{array}$ & $1,6-8$ & $23-25$ \\
\hline C. rhombus & $\begin{array}{c}0.85-0.97 \\
(0.92)\end{array}$ & $\begin{array}{c}0.64-0.66 \\
\quad(0.65)\end{array}$ & $\begin{array}{c}1.05-1.1 \\
(1.06)\end{array}$ & $\begin{array}{c}2.5-3.0 \\
(2.6)\end{array}$ & $\begin{array}{c}1.08-1.28 \\
(1.13)\end{array}$ & $1,6-8$ & 23 \\
\hline C. tavaresi & $\begin{array}{c}0.80-1.22 \\
(1.01)\end{array}$ & $\begin{array}{c}0.60-0.69 \\
(0.64)\end{array}$ & $\begin{array}{c}0.87-1.07 \\
(0.97)\end{array}$ & $\begin{array}{c}1.9-2.5 \\
(2.3)\end{array}$ & $\begin{array}{c}0.73-1.05 \\
(0.96)\end{array}$ & $1,(5) 6-8$ & $15-16$ \\
\hline
\end{tabular}

${ }^{a}$ : arranged alphabetically 
New records: One female, BRAZIL, Amazonas, Manaus, BR 174N km 50, 2०35'S $60^{\circ} 02^{\prime} \mathrm{W}, \mathrm{CDC}$ light trap, J. Arias col, 22.II.1979 (MLP); one female, Roraima, Maracá, $3^{\circ} 25^{\prime} \mathrm{N}$ 6140'W, "mata 1m", CDC light trap, E Castellón and S Gomes cols, 20.VI.1987 (ILMD).

Distribution: Mexico, Honduras, Costa Rica, Panama, Venezuela, Trinidad and Brazil (Amazonas, Pará and Roraima).

C. lyrinotatus Wirth and Blanton (Fig. 15, Table I) C. lyrinotatus Wirth and Blanton 1955: 126 (male, female; Panama; figs.); Forattini 1957: 435 (in neotropical catalog; figs.; distrib.); Wirth and Blanton 1959: 391 (redescript.; figs.; Panama records; distrib.); Wirth et al. 1988: 40 (Atlas; wing fig.; distrib.); Maes and Wirth 1990: 8 (distrib.; in catalog); Borkent and Wirth 1997: 73 (in catalog); Borkent and Spinelli 2000: 41 (in catalog; distrib.); Borkent and Spinelli 2007: 74 (in catalog; distrib.); Borkent 2014: 90 (in catalog).

Diagnosis: Female: $r_{3}$ with four pale spots in the proximal $1 / 2$ of cell; crossvein $\mathrm{R}-\mathrm{M}$ dark; $\mathrm{m}_{1}$ with two pale areas, the distal one far from wing margin; $\mathrm{CuA}_{2}$ with pale apex; mandible with 12 teeth. Male: sternite 9 with deep posteromedial excavation; aedeagus with basal arch extending to 0.8 of total length; parameres stem sinuous, distal portion with lateral fringe with four or five spicules.

Distribution: Nicaragua, Panama and Brazil (Pará).

C. macrostigma Wirth and Blanton (Fig. 16, Table I) C. macrostigma Wirth and Blanton 1953: 230 (male, female; Panama; figs.); Fox 1955: 245 (distrib.); Forattini 1957: 311 (in neotropical catalog, figs.; distrib.); Wirth and Blanton 1959: 395 (redescript.; figs.; Panama records; distrib.); Wirth et al, 1988: 40 (Atlas; wing fig.; distrib.); Borkent and Wirth 1997: 73 (in catalog); Borkent and Spinelli 2000: 41 (in catalog; distrib.); Borkent and Spinelli 2007: 74 (in catalog; distrib.); Borkent 2014: 90 (in catalog).

Diagnosis: Female: $r_{3}$ with four pale spots on proximal $1 / 2$ of cell; second radial cell $2.5 x$ longer than first, with pale lumen; $\mathrm{m}_{1}$ with two pale spots, the distal one far from wing margin; eyes contiguous; hind femur dark; AR 1.97; proboscis short, $\mathrm{P} / \mathrm{H}$ ratio 0.55 ; mandible with 11 teeth. Male: sternite 9 with shallow posteromedial excavation, ventral membrane spiculate; aedeagus with basal arch extending to $1 / 2$ of total length; parameres with basal knob bearing an elongate anterior process, without ventral lobes; distal portion bent laterally, ending abruptly.

Distribution: Costa Rica to Colombia.

C. martinezi Wirth and Blanton (Fig 17, Table I)

C. martinezi Wirth and Blanton 1970: 43 (male, female; Trinidad; figs.); Aitken et al. 1975: 133 (wing fig.; Trinidad records; distrib.); Wirth et al. 1988: 40 (Atlas; wing fig.; distrib.); Borkent and Wirth 1997: 74 (in catalog); Borkent and Spinelli 2000: 41 (in catalog; distrib.); Borkent and Spinelli 2007: 74 (in catalog; distrib.); Borkent 2014: 91 (in catalog).

Diagnosis: Female: $r_{3}$ with six pale spots arranged in two sets of triangles, one near the second radial cell and other in distal portion; $\mathrm{m}_{1}$ with three pale spots, the distal one not reaching wing margin; eyes broadly separated; mid and hind femur dark. Male: sternite 9 with shallow posteromedial excavation; aedeagus with basal arch extending to 0.75 of total length, distal portion with spiculate tip; parameres stout, with broad ventral lobes, distal portion with lateral fringe of spicules well developed.

Distribution: Trinidad.

C. paucienfuscatus Barbosa (Fig 18, Table I)

C. paucienfuscatus Barbosa 1947: 23 (female; Brazil (Amazonas) and Panama, key; figs.); Fox 1955: 251 (distrib.); Vargas 1949: 203 (in list); Forattini 1957: 345 (in neotropical catalog; figs.; Brazil (Pará) records; distrib.); Wirth and Blanton 1959: 381 (redescript.; figs.; distrib.); Williams 1964: 462 (bionomics); Wirth and Blanton 1973: 444 (Brazil (Amazonas and Pará) and Colombia records; distrib.); Aitken et al. 1975: 135 (key; wing fig.; Trinidad records; distrib.); Spinelli and Wirth 1986: 63 (key; wing fig.; Bolivia records; distrib.); Wirth et al. 1988: 40 (Atlas; wing fig.; distrib.); Borkent and Wirth 1997: 78 (in catalog); Silva and Rebêlo 1999: 169 (Brazil (Maranhão) 
records); Borkent and Spinelli 2000: 41 (in catalog; distrib.); Borkent and Spinelli 2007: 74 (in catalog; distrib.); Borkent 2014: 96 (in catalog).

Diagnosis: Female: Pale spots of the wing interconnected; $r_{3}$ with two pale spots, poststigmatic pale spot inverted L-shaped, isolating a dark spot behind second radial cell; $\mathrm{m}_{1}$ with two pale spots, the distal one reaching wing margin; $\mathrm{CuA}_{1}$ pale and $\mathrm{CuA}_{2}$ dark. Male: sternite 9 with moderately deep posteromedial excavation, ventral membrane spiculate; aedeagus with basal arch extending to $1 / 2$ of total length, distal portion spiculate; parameres sinuous without ventral lobes, distal portion with lateral fringe of spicules.

New records: one male, BRAZIL, Roraima, Maracá, $3^{\circ} 25^{\prime} \mathrm{N} 61^{\circ} 40^{\prime} \mathrm{W}$, “mata 10m”, CDC light trap, E Castellón and S Gomes cols, 26.VI.1987 (ILMD); one female, Goiás, Uruaçú, 14³1'S 4908'W, Shannon trap, CS Silva col, 21-29. IX.2000 (CCER).

Distribution: Costa Rica to Peru, Venezuela, Trinidad, Brazil (Amazonas, Pará, Roraima, Maranhão and Goiás) and Bolivia.

C. pifanoi Ortiz (Fig. 19, Table I)

C. pifanoi Ortiz 1951a: 588 (male, female; Venezuela; figs.); Ortiz 1954: 225 (descr.; var.); Fox 1955: 251 (tricoloratus syn.; distrib.); Forattini 1957: 342 (in neotropical catalog; figs., Panama and USA records; distrib.); Wirth and Blanton 1959: 384 (redescript.; Panama records); Williams 1964: 462 (bionomics); Wirth and Blanton 1973: 444 (Brazil (Pará) records; distrib.); Aitken et al. 1975: 136 (key; wing fig.; Trinidad records; distrib.); Spinelli and Wirth 1986: 63 (Brazil (Bahia) records); Wirth et al. 1988: 40 (Atlas; wing fig; distrib.); Maes and Wirth 1990: 9 (Nicaragua records; distrib.); Borkent and Wirth 1997: 79 (in catalog); Borkent and Spinelli 2000: 41 (in catalog; distrib.); Spinelli et al. 2005: 149 (key; Argentina and Paraguay records; wing fig.); Borkent and Spinelli 2007: 74 (in catalog; distrib.); Borkent 2014: 97 (in catalog).
C. tricoloratus Wirth and Blanton 1953: 233 (female, male; Panama).

Diagnosis: Female: $r_{3}$ with two pale spots; $\mathrm{m}_{1}$ with two pale spots the distal one far from wing margin; $\mathrm{CuA}_{1}$ dark, AR 0.84-1.02. Male: sternite 9 with shallow posteromedial excavation; aedeagus with basal arch extending to 0.75 of total length, distal portion flanked by a subapical pair of sclerotized lobes; parameres without ventral lobes, distal portion tapered to a subapical fringe of well developed spicules.

New records: Two females and one male, ECUADOR, Los Rios, Rio Palenque, "57 km N Quevedo", 101'S 79²7'W, UV light trap, J.S. Anderson col, 7.VIII. 1979 (MLP); BRAZIL: two males, Rio de Janeiro, Tijuca, Gavea Pequena, $22^{\circ} 58^{\prime}$ S

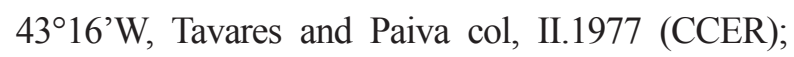
three males, same data except III.1977 (CCER).

Distribution: Belize to Colombia, Ecuador, Venezuela, Trinidad, Brazil (Pará, Bahia and Rio de Janeiro), Argentina and Paraguay.

\section{C. profundus Santarém, Felippe-Bauer and} Trindade (Fig. 20, Table I)

C. profundus Santarém et al. 2014: 266 (female; Brazil (Amazonas and Pará); figs.)

Diagnosis: Female: $r_{3}$ with four pale spots; $\mathrm{m}_{1}$ with two pale spots, the distal one far from wing margin; scutum with four median anterior yellowish spots arranged as a leaf clover; palpus 3rd segment swollen, with large, deep sensory pit in middle portion, opening in a small, rounded pore; PR 1.8-2.4; moderately long proboscis, $\mathrm{P} / \mathrm{H}$ ratio 0.86-0.95; mandible with 16 teeth. Male: unknown

Distribution: Brazil (Amazonas and Pará).

\section{C. pseudoreticulatus Santarém, Felippe-Bauer and Castellón (Fig. 21, Table I)}

C. pseudoreticulatus Santarém et al. 2014: 268 (female; Brazil (Amazonas and Roraima); figs)

Diagnosis: Female: $r_{3}$ with four pale spots; $m_{1}$ with two pale spots, the distal one far from wing margin; scuttum with four median anterior yellowish 
spots arranged as a leaf clover; palpus $3^{\text {rd }}$ segment with a shallow, round sensory pit in middle portion, with no well-defined contours on distal 1/2; PR 2.0 2.7; proboscis moderately long, $\mathrm{P} / \mathrm{H}$ ratio $1.0-1.06$; mandible with 19 teeth. Male: unknown

Distribution: Brazil (Amazonas and Roraima).

C. reticulatus Lutz (Fig. 22, Table I)

C. reticulatus Lutz 1913: 49 (female; Brazil (Rio de Janeiro, São Paulo and Bahia); fig. wing, male, larva; bionomy, larva in crab holes in mangrove edge; in part specimens from Bahia); Rieth 1915: 417 (bionomics data, based on Lutz 1913); Costa Lima 1937: 413 (key); Barbosa 1943: 261 (redescript.; male, female; Brazil (Pernambuco) records; figs.); Vargas 1945: 43 (in list); Barbosa 1947: 25 (key, distrib.); Macfie 1948: 73 (key); Vargas 1949: 205 (in list); Ortiz 1950a: 464 (distrib.); Iriarte 1950: 398 (in list); Fox 1955: 254 (in list); Forattini 1957: 432 (in neotropical catalog; figs.; distrib. in part specimens from Bahia and Pernambuco); Spinelli and Wirth 1986: 56 (key, wing fig.); Wirth et al. 1988: 42 (in Atlas; wing fig.; distrib. in part specimens from Brazil, not Pará); Borkent and Wirth 1997: 80 (in catalog); Borkent and Spinelli 2000: 41 (in catalog; distrib. in part specimens from Bahia and Pernambuco); Borkent and Spinelli 2007: 74 (in catalog; distrib. in part specimens from Bahia and Pernambuco); Borkent 2014: 99 (in catalog); Santarém et al. 2014: 257 (redescript.; Brazil (Bahia and Pernambuco); figs).

Diagnosis: Female: $r_{3}$ with four pale spots; $m_{1}$ with two pale spots, the distal one far from wing margin; scutum with four median anterior yellowish spots arranged as a leaf clover; eyes separated by diameter of $1 / 2$ ommatidium; palpus with shallow, rounded sensory pit in middle portion; PR 2.6-3.0 $(\mathrm{n}=6)$; proboscis long, $\mathrm{P} / \mathrm{H}$ ratio $1.14-1.17$. Male: parameres stem, slightly sinuous in median portion, without ventral lobes; basal arch of aedeagus extending $1 / 2$ of total length.

Distribution: Brazil (Pernambuco and Bahia).
C. rhombus Santarém, Felippe-Bauer and Castellón (Fig. 23, Table I)

C. rhombus Santarém et al. 2014: 270 (female; Brazil (Amazonas and Roraima); figs.)

Diagnosis: Female: $r_{3}$ with four pale spots; $m_{1}$ with two pale areas, the distal one far from wing margin; scutum with four median anterior yellowish spots arranged as a leaf clover; palpus $3^{\text {rd }}$ segment rhomboid, with a shallow, well-developed irregular sensory pit that reaches the extreme distal portion of segment; PR 2.5-3.0; proboscis long; $\mathrm{P} / \mathrm{H}$ ratio 1.08-1.28. Male: unknown

Distribution: Brazil (Amazonas and Roraima) C. tavaresi Felippe-Bauer and Wirth (Fig. 24, Table I) C. tavaresi Felippe-Bauer and Wirth 1988: 261 (male, female; Brazil (Rio de Janeiro); figs.); Borkent and Wirth 1997: 83 (in catalog); Borkent and Spinelli 2000: 41 (in catalog; distrib.); Borkent and Spinelli 2007: 74 (in catalog; distrib.); Borkent 2014: 102 (in catalog).

Diagnosis: Female: $r_{3}$ with three pale spots; $m_{1}$ with two pale spots, the distal one far from wing margin; halter dark; hind femur dark; mandible with 15-16 teeth. Male: sternite 9 with shallow posteromedial excavation; aedeagus with basal arch extending to 0.6 of total length; parameres with well-developed ventral lobes, distal portion with lateral fringe of spicules.

New records: One female, BRAZIL, Santa Catarina, Jaraguá do Sul, 26²9'S 4904'W (CCER); one female, same data except 21.III.2002 (CCER).

Distribution: Brazil (Rio de Janeiro and Santa Catarina).

\section{ACKNOWLEDGMENTS}

We are grateful to Tiago do Nascimento da Silva, for the edition and confections of figures plates; to Orlando Vicente Tobias and Rosimeire Lopes da Trindade from Museu Paraense Emílio Goeldi for the loan of part of the material for study; to Gustavo Spinelli for sending us the data of specimens deposited 

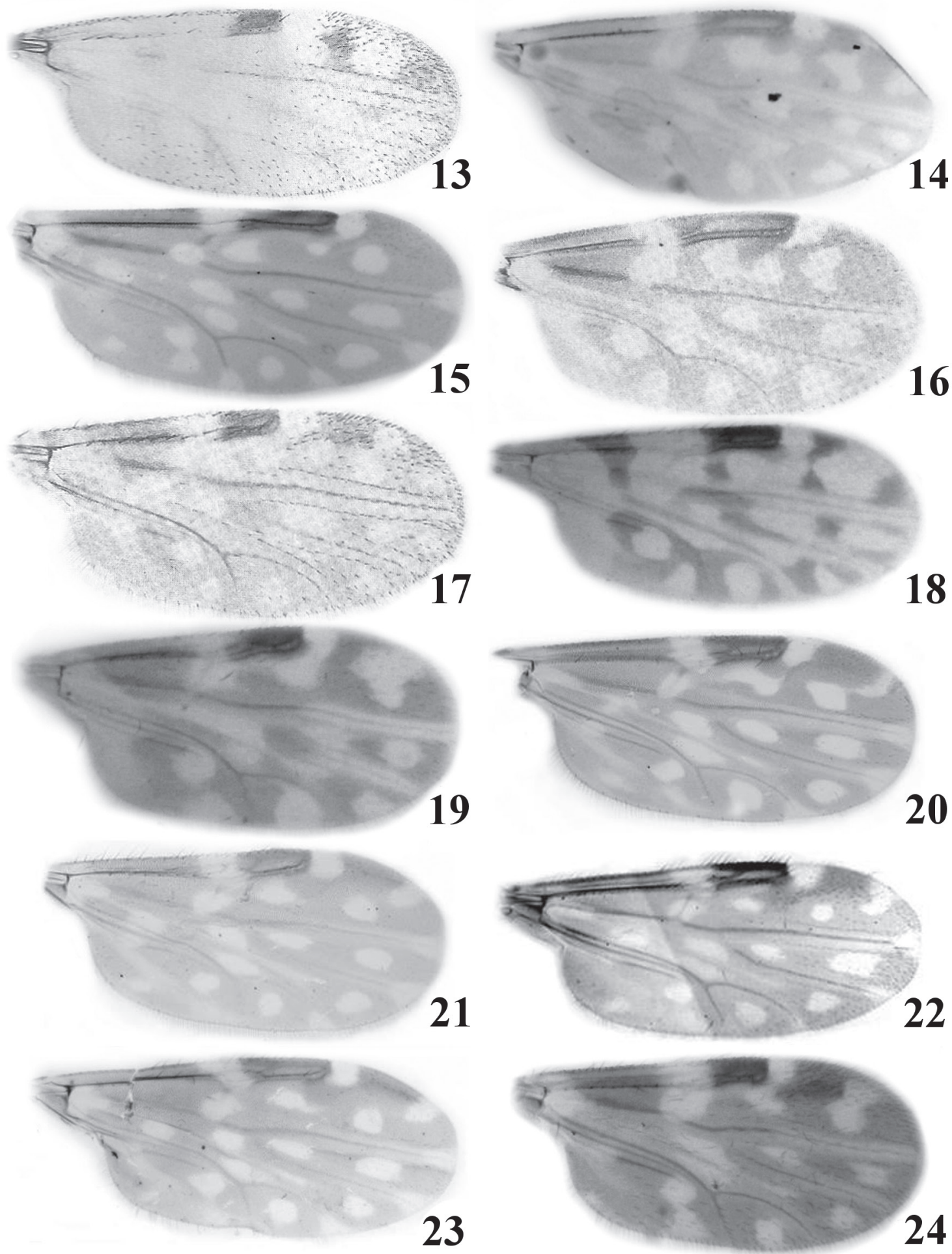

Figures 13-24 - Wing photograph of Culicoides reticulatus species group. 13. C. kuscheli. 14. C. lanei. 15. C. lyrinotatus. 16. C. macrostigma. 17. C. martinezi. 18. C. paucienfuscatus. 19. C. pifanoi. 20. C. profundus. 21. C. pseudoreticulatus. 22. C. reticulatus 23. C. rhombus. 24. C. tavaresi. 

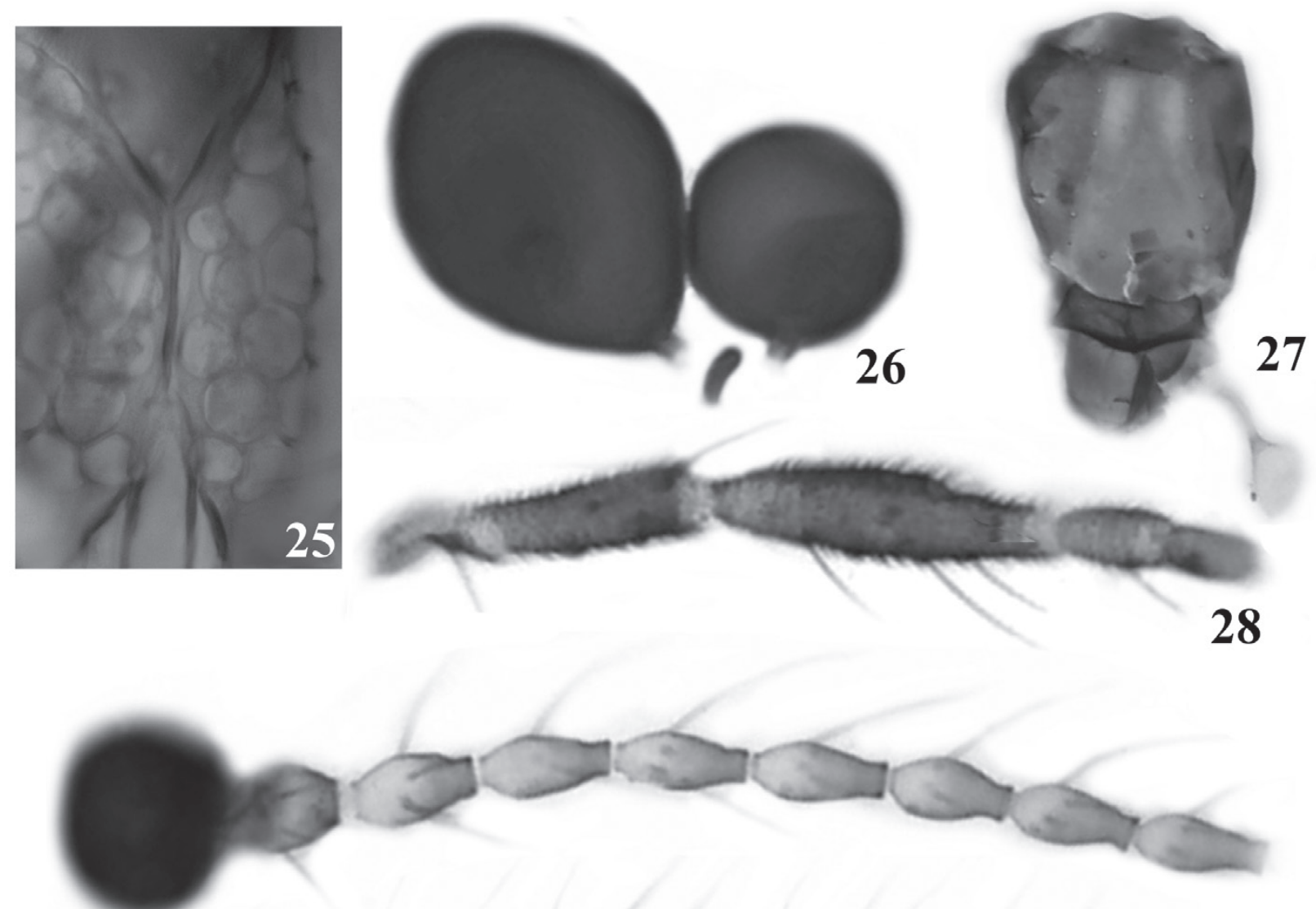

29
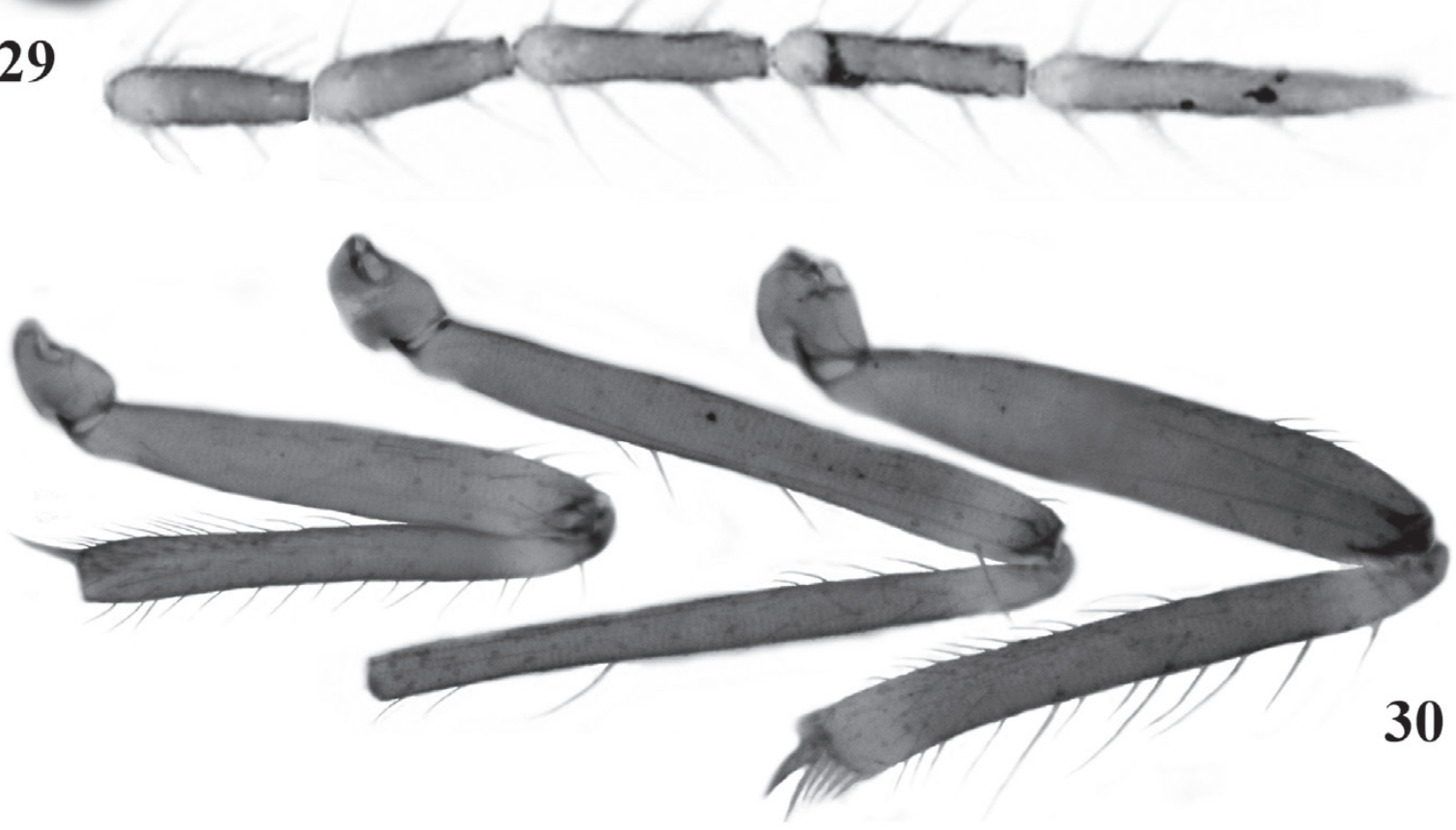

Figures 25-30 - Culicoides castelloni sp.nov, female holotype. 25. Eyes separation, anterior view. 26. Spermathecae. 27. Scutum. 28. Palpus. 29. Antenna. 30. Legs (left to right) fore, mid and hind. 
in Museo de La Plata; to Sérgio Luiz Bessa Luz for sending us part of the material of "CT- Amazônia Conselho Nacional de Desenvolvimento Científico e Tecnológico/Fundação de Amparo à Pesquisa do Estado do Amazonas (CNPq/FAPEAM)" project for study. We would also like to thank American Entomological Institute for the permission to use the photomicrographs of the species C. kuscheli, $C$. macrostigma and C. martinezi.

\section{RESUMO}

Uma nova espécie do grupo reticulatus, C. castelloni Santarém e Felippe-Bauer, é descrita e ilustrada baseada em espécimes fêmeas do estado do Amazonas, Brasil. São apresentadas uma chave sistemática, fotografia das asas e tabela com caracteres numéricos das fềmeas e uma sinopse das 24 espécies do grupo reticulatus. Este manuscrito apresenta também novos registros para sete espécies do grupo reticulatus.

Palavras-chave: maruins, grupo Culicoides reticulatus, Culicoides neotropicais, novos registros, nova espécie.

\section{REFERENCES}

Aitken THG, WiRTH WW, WiLliams RW, DAVIES JB AND TIKASINGH ES. 1975. A review of the bloodsucking midges of Trinidad and Tobago, West Indies (Diptera: Ceratopogonidae). J Entomo (B) 44: 101-144.

BARBOSA FAS. 1943. Descrição de Culicoides recifensis n. sp. e do macho de Culicoides reticulatus Lutz. Rev Bras Biol 3: 261-264.

BARBosa FAS. 1947. Culicoides (Diptera: Heleidae) da região neotropical. An Soc Biol Pernambuco 7: 3-30.

Borkent A. 2014. World Species of Biting Midges (Diptera: Ceratopogonidae). www.inhs.uiuc.edu/research/FLYTREE/ WorldCatalogtaxa.pdf.

Borkent A AND SpINELli GR. 2000. Catalog of the New World biting midges South of the United States of America (Diptera: Ceratopogonidae). Contrib Entomol Int 4: 1-107.

Borkent A AND SPINELli GR. 2007. Neotropical Ceratopogonidae (Diptera: Insecta). In: Adis J, Arias JR, Rueda-Delgado $G$ and Wnatzen KM (Eds), Aquatic Biodiversity in Latin America (ABLA), Pensoft, SofiaMoscow, 198 p.

BORKENT A AND WIRTH WW. 1997. World Species of Biting Midges (Diptera: Ceratopogonidae). Bull Am Mus Nat Hist 233: 1-257.
BROWN BV, BORKENT A, CUMMING JM, WOOD DM, WOODLEY NE AND ZUMBADO MA. 2009. Manual of Central America Diptera. NRC Research Press, Ottawa, 714 p.

Costa Lima AM. 1937. Chave das espécies de Culicoides da Região Neotropica (Diptera: Ceratopogonidae). Mem Inst Oswaldo Cruz 32: 411-422.

Felippe-Bauer ML, Damasceno CP, Trindade RL AND PY-DANIEL V. 2010. A new Culicoides (Diptera: Ceratopogonidae) of the reticulatus species group from Brazilian Amazon Region. Mem Inst Oswaldo Cruz 105: 863-865.

FELIPPE-BAUER ML AND WIRTH WW. 1988. Culicoides tavaresi, a new species from the state of Rio de Janeiro, Brazil (Diptera: Ceratopogonidae). Mem Inst Oswaldo Cruz 83: 261-263.

Floch H AND ABOnNENC E. 1942. Cératopogonides hématophages de la Guyane Française. Publ. Inst. Pasteur de la Guyane et du Territory de L'Inini 37: 1-10.

Forattini OP. 1957. Culicoides da Região Neotropical (Diptera: Ceratopogonidae). Arq Fac Hig Saude Publ 11: 161-524.

ForATtINI OP AND RABELlO EX. 1956. As formas imaturas de Culicoides guyanensis Floch e Abonnenc, 1942 e de algumas espécies de Stilobezzia (Diptera: Ceratopogonidae). Rev Bras Entomol 6: 43-49.

FoX I. 1946. A review of the species of biting midges or Culicoides from the Caribbean Region (Diptera: Ceratopogonidae). Ann Entomol Soc Am 39: 248-258.

Fox I. 1955. A catalogue of the bloodsucking midges of the Americas (Culicoides, Leptoconops and Lasiohelea) with keys to the subgenera and neartic species, a geographic index, and bibliography. J Agric Univ Puerto Rico 39: 214-285.

IRIARTE DR. 1950. Contribución al estudio de las ceratopogoninas hematófagas señaladas en Venezuela. Bol laboratório clinica Luis Razetti 15: 344-413.

KHALAF K. 1954. The speciation of the genus Culcoides (Diptera: Heleidae). Ann Entomol Soc Am 47: 34-51.

LAENDER JO, RibeIRo ES, GOUVEIA AMG, LOBATO ZIP AND FELIPPE-BAUER ML. 2004. Levantamento das espécies de Culicoides Latreille, 1809 (Diptera: Ceratopogonidae) encontradas nas mesorregiões Norte de Minas, Jequitinhonha e Vale do Mucuri, Minas Gerais, Brasil. Entomol Vect 11: 145-157.

LUTZ A. 1913. Contribuição para o estudo das Ceratopogoninas hematofagas do Brazil. Mem Inst Oswaldo Cruz 5: 45-73.

MACFIE JWS. 1948. Some species of Culicoides (Diptera: Ceratopogonidae) from the State of Chiapas, Mexico. Ann Trop Med Parasitol 48: 67-87.

MAes JM AND WIRTH WW. 1990. Catálogo de los Diptera de Nicaragua. 6. Ceratopogonidae (Nematocera). Rev Nicaraguense Entomol 14: 1-17.

ORTIZ I. 1950a. Informes sobre una nueva especie y lista de los machos cuyas genitalias son conocidas. Rev Sanid Asist Soc 15: 461-465. 
ORTIZ I. 1950b. Estudios en Culicoides II. Diptera, Ceratopogonidae. Culicoides lanei n. sp. de Panama. Rev Sanid Asist Soc 15: 431-433.

ORTIZ I. 1951a. Estudios en Culicoides (Diptera, Ceratopogonidae). IX. Sobre los caracteres diferenciales entre Culicoides paraensis (Goeldi, 1905), C. stellifer (Coquillett, 1901), y C. lanei (Ortiz, 1950). Descipción de cuatro nuevas especies con la redescripción de algunas otras poco conocidas. Rev Sanid Asist Soc 16: 573-591.

ORTIZ I. 1951b. Estudios sobre Culicoides (Diptera, Ceratopogonidae) VII. Culicoides dominicii n. sp. y clave para el reconocimiento de las especies venezolanas. Nov Cient, Contrib Ocasionales Museo Hist Nat La Salle, Serie Zoologica 5: 1-12.

ORTIZ I. 1954. Sobre dos nuevos dipteros hematofagos del genero Culicoides (Nematocera, Ceratopogonidae). Arch Venezolanos Patol Trop Parasitol Med 2: 221-226.

ORTIZ I. 1961. Descripcion de una nueva especie de Culicoides (C. forattinii sp. n.) del subgenero Oecacta Poey, 1851, de Venezuela. Rev Bras Entomol 10: 211-215.

RIETH JT. 1915. Die Metamorphose der Culicoidien (Ceratopogoninen). Archiv für Hydrobiologie suppl 2: 377-443.

Ronderos MM AND SPINELLi GR. 1998. Las especies de Culicoides en el área de influencia de la represa de Yacyretá (Diptera: Ceratopogonidae). Rev Soc Entomol Argent 57: 79-83.

RONDEROS MM, SPINELLI GR, LAGER I AND DÍAZ F. 2003. La importancia sanitaria dos jejenes del genero Culicoides (Diptera: Ceratopogonidae) en la Argentina. Entomol Vect 10: 601-612.

SANTARÉm MCA, Trindade RL, Silva TN, CASTEllón EG, Mello-Patiu CA ANd Felippe-Bauer ML. 2014. New Neotropical Culicoides and redescription of Culicoides reticulatus Lutz (Diptera: Ceratopogonidae). Zootaxa 3795: 255-274.

SILVA FS AND REBÊLO JMM. 1999. Espécies de Culicoides Latreille (Diptera: Ceratopogonidae) da Ilha de São Luís, Maranhão, Brasil. Bol Museu Paraense Emilio Goeldi 15: 169-179.

SPINELLI GR, Ronderos MM, DíAZ F AND MARINO P. 2005. The bloodsucking biting midges of Argentina (Diptera: Ceratopogonidae). Mem Inst Oswaldo Cruz 100: 137-150.
SPINELli GR AND WIRTH WW. 1986. Clave para la identificacion de las especies del genero Culicoides Latreille presentes al sur de la cuenca amazonica. Nuevas citas y notas sinonimicas (Diptera: Ceratopogonidae). Rev Soc Entomol Argent 44: 49-73.

VARGAS L. 1945. Nota sobre ceratopogonidos y Culicoides. Rev Inst salub enferm trop 6: 42-49.

VARGAS L. 1949. Lista de los Culicoides del mundo (Diptera: Heleidae). Rev Soc Mexicana Hist Nat 10: 191-218.

WiLliams RW. 1964. Observations on Habitats of Culicoides Larvae in Trinidad, W. I. (Diptera: Ceratopogonidae). Ann Entomol Soc Am 57: 462-466.

WiRTH WW AND Blanton FS. 1953. Studies in Panama Culicoides (Diptera, Heleidae). II. Descriptions of six additional new species. J Parasitol 39: 229-236.

WirTH WW AND BLANTON FS. 1955. Studies in Panama Culicoides (Diptera, Heleidae) V. Descriptions of three new species of the subgenus Oecacta Poey. Bull Brooklyn Entomol Soc 50: 121-127.

WiRTH WW AND BLANTON FS. 1959. Biting midges of the genus Culicoides from Panama (Diptera: Heleidae). Proc US Nat Mus 109: 237-482.

WiRTH WW AND BLANTON FS. 1970. New species of Neotropical Culicoides (Diptera: Ceratopogonidae). Florida Entomol 53: 39-45.

WIRTH WW AND BLANTON FS. 1973. A review of the maruins or biting midges of the genus Culicoides (Diptera: Ceratopogonidae) in the Amazon Basin. Amazoniana 4: 405-470.

WiRTH WW AND Blanton FS. 1978. Two new species of Neotropical Culicoides (Diptera: Ceratopogonidae). PanPacific Entomol 54: 236-240.

WiRTH WW, DyCE AL AND SPINELli GR. 1988. An atlas of wing photographs with a summary of the numerical characters of the neotropical species of Culicoides (Diptera: Ceratopogonidae). Contr Am Entomol Inst 25: $1-72$.

WirTh WW AND MARSTON N. 1968. A method for mounting small insects on microscope slides in Canada Balsam. Ann Entomol Soc Am 61: 783-784. 